\title{
Diagnosis and Integrated Management of Fruit Rot in Cucurbita argyrosperma, Caused by Sclerotium rolfsii
}

\author{
José Francisco Díaz Nájera ${ }^{1}$, Jaime Sahagún Castellanos ${ }^{2}$, Mateo Vargas Hernández ${ }^{\circledR}{ }^{3 *}$, Sergio Ayvar Serna ${ }^{4}$, \\ Omar Guadalupe Alvarado Gómez ${ }^{5}$, Clemente Villanueva Verduzco ${ }^{2}$, and Marcelo Acosta Ramos ${ }^{6}$ \\ ${ }^{1}$ Postgraduate in Horticulture, Chapingo Autonomous University, Texcoco 56227, Mexico \\ ${ }^{2}$ Department of Crop Sciences, Postgraduate in Horticulture, Chapingo Autonomous University, Texcoco 56227, Mexico \\ ${ }^{3}$ Department of Soils Sciences, Postgraduate in Plant Protection, Chapingo Autonomous University, Texcoco 56227, \\ Mexico \\ ${ }^{4}$ Center of Professional Studies, Superior Agricultural College of the State of Guerrero, Iguala, Guerrero 40000, Mexico \\ ${ }^{5}$ Faculty of Agronomy, Nuevo Leon Autonomous University, San Nicolás de los Garza, Nuevo León 66451, Mexico \\ ${ }^{6}$ Department of Parasitology, Postgraduate in Plant Protection, Chapingo Autonomous University, Texcoco 56227, \\ Mexico
}

(Received on August 27, 2017; Revised on February 3, 2018; Accepted on February 19, 2018)

Fruit rot is the principal phytopathological problem of pipiana pumpkin (Cucurbita argyrosperma Huber) in the state of Guerrero. The aims of this research were to 1) identify the causal agent of southern blight on pumpkin fruits by morphological, pathogenic, and molecular analysis (ITS1, 5.8S, ITS2); 2) evaluate in vitro Trichoderma spp. strains and chemical fungicides; and 3) evaluate under rainfed field conditions, the strains that obtained the best results in vitro, combined with fungicides during two crop cycles. Number of commercial and non-commercial fruits at harvest, and seed yield $\left(\mathrm{kg} \mathrm{ha}^{-1}\right)$ were registered. Morphological, pathogenic and molecular characterization identified Sclerotium rolfsii as the causal agent of rot in pipiana pumpkin fruits. Now, in vitro conditions, the highest inhibition of $S$. rolfsii were obtained by Trichoderma virens strain G-41 (70.72\%), T. asperellum strain CSAEGro-1 (69\%), and the fungicides metalaxyl (100\%), pyraclostrobin $(100 \%)$, quintozene $(100 \%)$, cyprodinil + fludioxonil

*Corresponding author.

Phone) +52-59595-41634, FAX) +52-59595-41634

E-mail)vargas_mateo@hotmail.com

ORCID

https://orcid.org/0000-0002-0735-3242

(c) This is an Open Access article distributed under the terms of the Creative Commons Attribution Non-Commercial License (http:// creativecommons.org/licenses/by-nc/4.0) which permits unrestricted noncommercial use, distribution, and reproduction in any medium, provided the original work is properly cited.

Articles can be freely viewed online at www.ppjonline.org. $(\mathbf{1 0 0 \%})$, and prochloraz (100\%). Thiophanate-methyl only delayed growth $(4.17 \%)$. In field conditions, during the spring-summer 2015 cycle, $T$. asperellum strain CSAEGro-1 + metalaxyl, and T. asperellum + cyprodinil + fludioxonil, favored the highest number of fruits and seed yield in the crop.

Keywords : fungicides, integrated management, Pumpkin, Sclerotium rolfsii, Trichoderma

Handling Associate Editor : Lee, Jungkwan

The pipiana pumpkin (Cucurbita argyrosperma Huber) is an annual crop cultivated in a traditional agricultural production system, during the rainy season. The crop is cultivated during the months of May and June and is harvested from September to December (Ayvar et al., 2007). The main product obtained from pipana pumpkin cultivation is the mature seed, which has great acceptance for its consumption in different dishes of Mexican cuisine; and is used in the industry as raw material to prepare mole paste. The crop is affected by different phytopathogenic fungi, but those that live in the soil are those that cause severe damages from the beginning of the fruiting stage until harvesting (Diaz et al., 2015). The infection occurs in fruits that are in contact with the soil and the disease development is favored by warm and humid conditions. Infected pumpkin fruits are lost because the pathogens are destructive (Zitter et al., 2004). In this regard, Díaz et al. (2014) 
mention that the damage of highest economic impact is fruit rot that occurs just before harvest because it drastically reduces seed yield and threatens the successful economic investment of the farmer. To reduce damages, the causal agent must be combated by previous diagnose, through integrated management, where the use of different methods is highly recommended, such as cultural practices, as well as the use of beneficial microorganisms, and the application of chemical products. The use of chemical fungicides is the method that farmers prefer; however, in the state of Guerrero, there is limited information on integrated management of rot in pumpkin fruits. Ayvar et al. (2007) and Díaz et al. (2015) have reported the incidence of oomycetes and deuteromycetes in pipiana pumpkin; they recommend applying specific products such as benomyl and metalaxyl, among others; however, the fungicide validation in the crop is very scarce. In the integrated and sustainable management, control methods must be incorporated in order to reduce the use of chemical molecules, such as applying the genus Trichoderma, a biocontrol agent with high expectations for fungi management in pumpkin, because it has the advantage of being harmless to humans and animals, and does not pollute ecosystems. To achieve success in the integrated management of rot in pipiana pumpkin fruits, it is important to know the history of the cultivated plots taking into account climate information, and the application of biocontrol agents and fungicides in a preventive and never in a curative manner. The aims of the research were: a) to identify, through morphological, molecular and pathogenic techniques, the causal agent of rot in pumpkin fruits, b) to evaluate in vitro the biological effectiveness of commercial and native Trichoderma spp strains, and fungicides and c) to evaluate in the field, under rainfed conditions, the two strains that obtained the best results in vitro combined with fungicides during two consecutive crop cycles.

\section{Materials and Methods}

Isolation and purification. In September and October 2014, 20 mature pipiana pumpkin fruits were collected, in a $60,000 \mathrm{~m}^{2}$ commercial plot, established in valle de El Zoquital, Apipilulco, municipality of Cocula, in the northern part of the State of Guerrero, located at the coordinates $18^{\circ} 1106.30^{\prime \prime}$ North latitude and $99^{\circ} 37^{\prime} 36.60^{\prime \prime}$ West longitude, at 620 masl. The typical soil type is loamy-clay, with rainfall and average annual temperature of $1000 \mathrm{~mm}$ and $30^{\circ} \mathrm{C}$. The $\mathrm{W}$-transect type sampling method was used; where fruits with patches of white fluffy mycelium (in contact with the soil), and with sclerotia were collected. From mature pumpkin fruits, samples with symptoms and signs of rot, five pieces of $0.5 \mathrm{~cm}^{2}$ tissue were cut from the advancing disease area. Samples were disinfected with $1.5 \%$ sodium hypochlorite for two minutes, washed three consecutive times with sterile distilled water; 50 tissue samples were placed in Petri dishes containing potato dextrose agar $(\mathrm{PDA})$ and incubated at room temperature $\left( \pm 28^{\circ} \mathrm{C}\right)$ with $12 / 12 \mathrm{~h}$ photoperiod for 5 days.

Morphological identification. The developed fungal colonies were separated and purified by the hyphal tip method in Petri dishes with PDA medium. Temporary preparations in lactophenol were carried out using mycelium samples of the isolated and purified pathogens which were observed in a composite microscope at $40 \mathrm{X}$ and 100X lenses, the principal taxonomic characteristics such as color, septation, and branching of the hyphae, as well as the presence of sclerotia was compared to the illustrated keys described by Watanabe (2002); which made it possible to carry out the identification of the fungus.

Pathogenicity test. For the pathogenicity test, five fruit samples were used, washed with running tap water, and the surface was sterilized with $0.2 \%$ sodium hypochlorite $(\mathrm{NaOCl})$ for $2 \mathrm{~min}$. Then, washed three times with sterile distilled water. Prick inoculation was performed on the fruit epicarp using mature mycelium of the fungus with a sterilized dissecting needle. Inoculated fruits were kept in a moist chamber at $70 \%$ relative humidity and incubated for 7 days at $28 \pm 2^{\circ} \mathrm{C}$. Fruits inoculated with sterile distilled water were used as the control.

Molecular identification. Genomic DNA extraction of the isolates was performed from 7 days old mycelia sample using the DNeasy ${ }^{\mathrm{TM}}$ kit (QIAGEN ${ }^{\circledR}$, Hilden, Germany) according to the manufacturer's instructions. The PCR reactions were carried out using oligonucleotides ITS1 (5'-TCCGTAGGTGAACCTGCGG-3') and ITS4 (5'-TCCTCCGCTTATTGATATGC-3') (White et al., 1990), which amplify the internal transcribed spaces and the 5.8S gene of the ribosomal DNA (ITS region) and generate a product of varying size, between approximately 500 and 600 base pairs (bp) (White et al., 1990). This practice was carried out in the reaction mixture in a final volume of $25 \mu \mathrm{l}$, whose final components were $1 \mathrm{X}$ reaction buffer, $2 \mathrm{mM} \mathrm{MgCl} 2,200 \mathrm{nM}$ of each dNTPs, 20 pmol of each primer and 1 unit of Taq DNA polymerase (Promega, WI, USA). The thermal program consisted of maintaining a temperature at $94^{\circ} \mathrm{C}$ for $2 \mathrm{~min}$, followed by 35 cycles at 94-55-72 ${ }^{\circ} \mathrm{C}$ for $30-30-60 \mathrm{~s}$ and a final extension of $5 \mathrm{~min}$ at $72^{\circ} \mathrm{C}$. The PCR-amplified fragments were observed 
in a UV light transilluminator and sequenced directly on an ABI PRISM ${ }^{\circledR} 3700$ Genetic Analyzer (Foster City, CA, USA). The consensus sequences were edited and assembled with the CAP option (Contig Assembly Program) (Hall, 2004) of the BioEdit 7.2.5 Software (Tom Hall, Ibis Biosciences, Carlsbad, CA, USA) (Hall, 2004). In the evolutionary analysis, all consensus sequences were aligned with the ClustalW program (Thompson et al., 1994) included in the MEGA 7 software (Kumar et al., 2016). Phylogenetic reconstructions were performed for the ITS15.8S-ITS2 data based on the maximum parsimony method, using the algorithm Subtree-Pruning-Regrafting, search option (level $=1)$ with the initial tree by random addition (10 replicates) and the missing spaces were considered as complete deletions. To calculate the confidence values of tree clades, a bootstrap test with 1000 replicates was performed (Felsenstein, 1985). The sequence obtained was deposited in the GenBank database.

Biological control of the causal agent of rot in pumpkin fruits in vitro. Three commercial and three native Trichoderma spp strains; those of the second group were provided by the Laboratory of Phytopathology of the Superior Agricultural College of the state of Guerrero (CSAEGro), which were originally obtained by the plate dilution technique and were reactivated by transferring them in Petri dishes with PDA. Similarly, the commercial isolates were obtained in pure culture, with the same procedure and were reactivated on PDA. The treatments evaluated were: T1: Control, T2: Trichoderma fasciculatum, T3: Trichoderma virens Strain G-41, T4: Trichoderma reesei, T5: Trichoderma asperellum Strain CSAEGro-1, T6: Trichoderma asperellum Strain CSAEGro-2 and T7: Trichoderma sp. Strain Santa Teresa. To evaluate the antibiosis of the Trichoderma strains, the cellophane technique described by Patil et al. (2014) was used; first, cellophane paper was cut in circles of $8.5 \mathrm{~cm}$ in diameter, same as the size of the Petri dish; was then sterilized and placed on PDA; with a $0.5 \mathrm{~cm}$ diameter cockborer. PDA discs with 3-day old Trichoderma spp colonies were placed in the center of the dish, after incubating for $48 \mathrm{~h}$, the paper with the active Trichoderma spp colonies was removed, so that the secondary metabolites can diffuse in the culture medium, in which the fungistatic effect was immediately evaluated by placing in the center of the petri dish, PDA with mycelium from a 3- day old pathogenic colony and incubating the dishes at room temperature $\left(28 \pm 2^{\circ} \mathrm{C}\right)$ in the laboratory. A completely randomized design with five replicates was used. The experimental unit consisted of one Petri dish 8.5 and $9.0 \mathrm{~cm}$ in diameter, and $1.5 \mathrm{~cm}$ in height, with $20 \mathrm{ml}$ of PDA culture medium + Trichoderma spp metabolites. The percent of inhibition was determined by the equation: inhibition $\%=((\mathrm{D} 1-\mathrm{D} 2) / \mathrm{D} 1) \times(100)$ where: $\mathrm{D} 1=$ diameter of the pathogen colony (control) and D2 $=$ diameter of the pathogen fungal colony growing in Petri dish with PDA medium where Trichoderma spp. had grown (Patil et al., 2014). An analysis of variance and multiple mean comparison test was performed with the data obtained from the variable using Tukey's honest significant difference method with significance level at 5\% (Statistical Analysis System, 2015).

Chemical control of the causal agent of rot in pumpkin fruits in vitro. The experiment was established to study the effect of different fungicides on the development of the identified fungus, using the poisoned culture media technique (Sohbat et al., 2015). The following commercial chemical products were used at the doses recommended by the manufacturer T1: Control, T2: Metalaxyl, T3: Pyraclostrobin, T4: Thiophanate methyl, T5: Quintozene (PCNB), T6: Cyprodinil + fludioxonil and T7: Procloraz, where $20 \mathrm{~mL}$ PDA was added to the Petri dishes that contained the doses of fungicide and was allowed to solidify at room temperature $\left(28 \pm 2^{\circ} \mathrm{C}\right)$. Then a PDA disc $(0.5$ $\mathrm{cm}$ diameter) with fungal mycelium was placed in the center of the Petri dish; they were labeled and incubated in the laboratory. A completely randomized design with five replicates was used. The experimental unit consisted of one Petri dish. To determine the effect of the chemical molecules on the development of the causal agent of rot in pumpkin fruit, the percentage of inhibition was measured in the same manner as described above. Statistical analysis was also similar to that performed in the first in vitro essay. All statistical analysis were performed using the Statistical Analysis System version 9.4 program (Statistical Analysis System, 2015).

Integrated control of the causal agent of rot in pumpkin fruits in field conditions. This phase consisted of evaluating under field conditions, the two most outstanding Trichoderma isolates obtained from the first in vitro essay and the fungicides used in the second in vitro phase.

Experimental site. The experiment was conducted during two crop cycles, in the spring-summer of 2015 and 2016, under rainfed conditions, at the experimental field of the Superior Agricultural College of the state of Guerrero, Cocula, Guerrero ( $18^{\circ} 14^{\prime} \mathrm{NL}, 99^{\circ} 39^{\prime} \mathrm{WL}$ and at 640 masl). The climate is AW0, which corresponds to a warm sub-humid climate with summer rains, average annual 
Table 1. Treatments evaluated in field conditions against the causal agent of fruit rot in pumpkin: Thrichoderma + fungicide

\begin{tabular}{|c|c|c|}
\hline Symbology & Trichoderma (Strain) & Fungicide \\
\hline $\mathrm{T} 1$ & Control & Control \\
\hline $\mathrm{T} 2$ & Trichoderma asperellum (CSAEGro-1) & TOKAT $^{\circledR} 240$ CE (Agroquímicos Versa, Coahuila, Mexico) \\
\hline $\mathrm{T} 3$ & Trichoderma asperellum (CSAEGro-1) & HEADLINE $^{\circledR}$ (BASF, Ludwigshafen, Germany) \\
\hline $\mathrm{T} 4$ & Trichoderma asperellum (CSAEGro-1) & CERCOBIN $^{\circledR}-\mathrm{M}$ (BASF, Ludwigshafen, Germany) \\
\hline T5 & Trichoderma asperellum (CSAEGro-1) & PENTACLOR $^{\circledR} 600$ F (ARYSTA lifescience, Coahuila, Mexico) \\
\hline T6 & Trichoderma asperellum (CSAEGro-1) & SWITCH $^{\circledR}$ 62.5 WG (Syngenta Australia Pty Ltd., Macquarie Park, Australia) \\
\hline $\mathrm{T} 7$ & Trichoderma asperellum (CSAEGro-1) & SPORTAK 45 CE (FMC Agrochemistry, Mexico City, Mexico) \\
\hline $\mathrm{T} 8$ & Trichoderma virens (PHC RootMate ${ }^{\circledR}$ ) & TOKAT $^{\circledR} 240 \mathrm{CE}$ \\
\hline T9 & Trichoderma virens (PHC RootMate ${ }^{\mathbb{}}$ ) & HEADLINE $^{\circledR}$ \\
\hline $\mathrm{T} 10$ & Trichoderma virens (PHC RootMate ${ }^{\circledR}$ ) & CERCOBIN $^{\circledR}-\mathrm{M}$ \\
\hline $\mathrm{T} 11$ & Trichoderma virens (PHC RootMate ${ }^{\mathbb{}}$ ) & PENTACLOR $^{\circledR} 600 \mathrm{~F}$ \\
\hline $\mathrm{T} 12$ & Trichoderma virens (PHC RootMate ${ }^{\mathbb{}}$ ) & $\mathrm{SWITCH}^{\circledR} 62.5 \mathrm{WG}$ \\
\hline $\mathrm{T} 13$ & Trichoderma virens (PHC RootMate ${ }^{\mathbb{Q}}$ ) & SPORTAK 45 CE \\
\hline
\end{tabular}

temperatures of $26.4^{\circ} \mathrm{C}$, and $23.4^{\circ} \mathrm{C}$ in the coldest month (December). The temperature oscillation from one month to another is from 5 to $7^{\circ} \mathrm{C}$. The average annual rainfall is $767 \mathrm{~mm}$. The soil is vertisol with $\mathrm{pH} 7.1$, electrical conductivity $0.23 \mathrm{dS} \cdot \mathrm{m}^{-1}$, organic matter $1.7 \%$, total $\mathrm{N} 0.1 \%$ and phosphorus $14 \mathrm{ppm}$. The native genotype "Apipilulco", the most cultivated in the study area was used, reaching maturity at 100-110 days after emergence (d.a.e.).

Treatments and experimental design. A split plot experimental design, with whole plots arranged in completely randomized block design, was used. The whole plots corresponded to two Trichoderma strains, and the sub-plots to fungicides; four replicates were used, the treatments are described in Table 1. The experimental unit consisted of 12 plants, and due to the crop characteristics (indeterminate creeping growth), the entire experimental unit was considered as the useful plot. The treatments were applied twice using an Arimitsu ${ }^{\circledR}$ motorized pump (Model SD-260D, ROGAVAL S.A. of C.V., Mexico State, Mexico), with a 2-point flat-fan KS-K6 nozzle at 80 psi. With a water expenditure of $8001 \mathrm{ha}^{-1}$. The $\mathrm{pH}$ of the water was adjusted to 7 (Agrex ${ }^{\circledR}$ ABC, Agroenzymas S.A. of C.V., Mexico State, Mexico) and the adjuvant (Inex- $\mathrm{A}^{\circledR}$, Cosmocel S.A., Nuevo León, Mexico) was added at a doses of $1 \mathrm{ml}^{-1}{ }^{-1}$. The Trichoderma strains were applied to the soil at 20 and 35 days after emergence (d.a.e.) and the fungicides, at 60 and 75 d.a.e. The number of commercial fruits harvested in $35 \mathrm{~m}^{2}$ (mature fruits without damage); number of noncommercial fruits also harvested in $35 \mathrm{~m}^{2}$ (mature fruits with some symptoms or level of fungal damage) and seed yield in $\mathrm{kg} \mathrm{ha}^{-1}$ were evaluated. Data of each variable were analyzed using individual analysis of variance for each of the cycles and combined through the 2 cycles. Likewise, multiple comparison test using the Tukey method with significance level at 5\% was used. All statistical analyses were performed using the Statistical Analysis System (Statistical Analysis System, 2015).

\section{Results and Discussion}

Morphological identification. Based on cultural and morphological features, the fungal pathogen was identified as Sclerotium rolfsii Sacc. [Teleomorph: Athelia rolfsii (Curzi) Tu and Kimbrough]. This fungus is characterized by abundant production of cottony aerial mycelium; rapid aerial mycelium growth (Fig. 1E), septal hyphae, hyaline, branched and thin-walled (Fig. 1A, 1B) with and without clamp connections (fibulas) (Fig. 1C, 1D) forming abundant light brown sclerotia, $1.0-1.5 \mathrm{~mm}$ in diameter, globose to subglobose, smooth surface, glossy and compacted (Fig. 1E, 1F) (Watanabe, 2002).

Pathogenicity test. Soft rot symptoms appeared 7 days after inoculating Sclerotium rolfsii in mature pumpkin fruits (Fig. 2 right) in which abundant white cottony aerial mycelium of an aqueous consistency was observed, symptoms and signs were similar to those observed in the field. The control fruits remained healthy (Fig. 2 left). The reisolation of the fungus obtained from the infected tissue of inoculated fruits presented the same morphological characteristics as those that were originally isolated.

Molecular identification. The obtained sequence (570 bp) showed $100 \%$ similarity to the ITS region, whose alignment coincided with sequences reported in the Gen Bank 


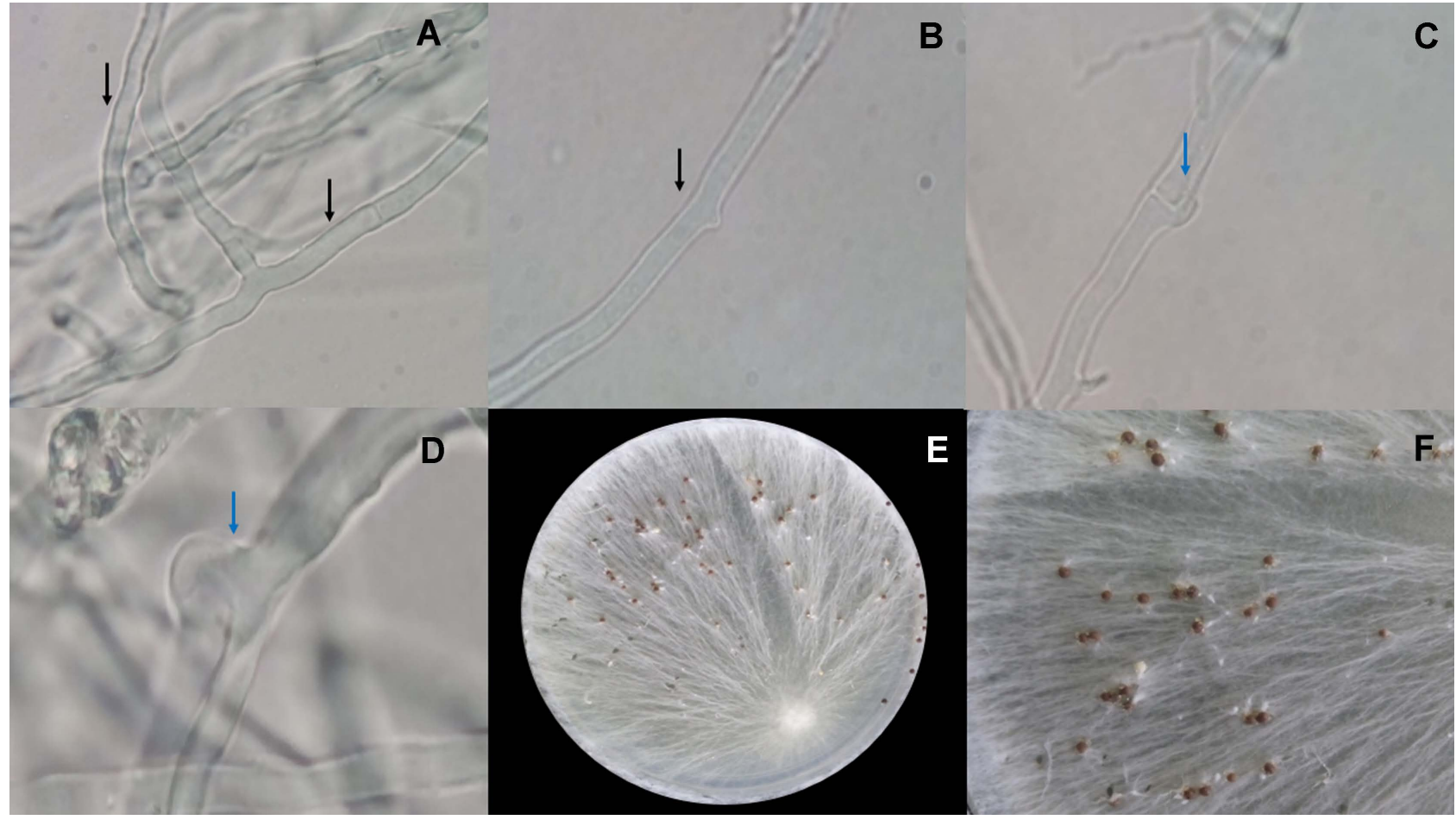

Fig. 1. Morphological identification of Sclerotium rolfsii. (A) and (B) Mycelium (black arrows), (C) and (D) Clamp connection (blue arrows), (E) Cultivation in PDA, (F) Formation of sclerotia.

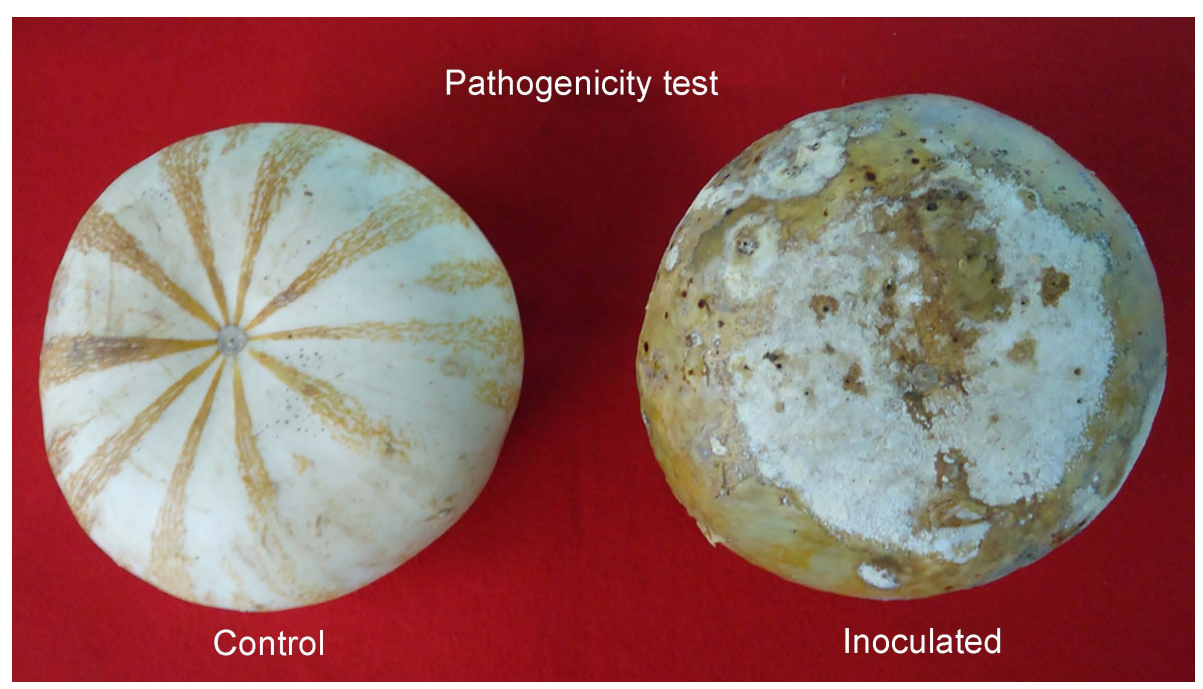

Fig. 2. Pathogenicity test of Sclerotium rolfsii in Curcurbita argyrosperma fruits. Control fruit (left) and inoculated fruit (right). for Athelia rolfsii (Curzi) Tu \& Kimb [Anamorph: Sclerotium rolfsii Sacc.]. The accession KX757771.1 CSAEGroCaDIA was deposited in the Genbank of the National Biotechnology Information Center (Fig. 3). The species was identified as $A$. rolfsii in the phylogenetic reconstruction based on the use of ITS region. The ITS region was able to separate the identified pathogen and the $S$. rolfsii strain (JX566993), from the rest of the species of the same genus, with a bootstrap reliability of $73 \%$, besides being highly differentiated from the rest of the species (100\%) (Fig. 3).

Biological control of Sclerotium rolfsii causal agent of rot in pumpkin fruit in vitro. For the three samples of the pathogen growth colonies, the mean values showed highly significant differences $(P<0.0001$ and $P=0.0042)$. The lowest growth was observed in treatments with Tricho- 


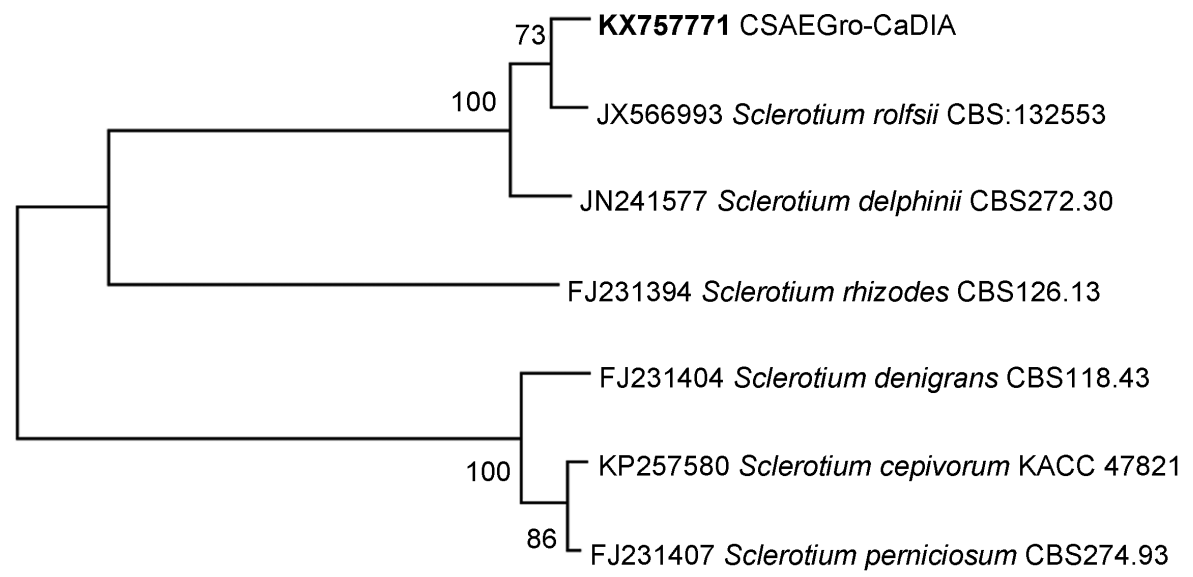

Fig. 3. Phylogenetic tree obtained by the maximum parsimony method using the Subtree-Pruning-Regrafting algorithm. The confidence values of the nodes were formed with 1000 bootstrap replicates. Remarked letter in bold, evaluated strains in this study. s. 1. = sensu lato.

Table 2. Mean values of the diameter $(\mathrm{cm})$ of the colony of Sclerotium rolfsii, in Test I of in vitro antibiosis by the cellophane technique

\begin{tabular}{clccc}
\hline \multirow{2}{*}{ Treatments } & \multicolumn{1}{c}{ Fungal strains } & \multicolumn{2}{c}{ Diameter $(\mathrm{cm})$ of the colony of S. rolssii } \\
\cline { 2 - 4 } & & Sampling 1 & Sampling 2 & Sampling 3 \\
\hline T1 & Control & $2.96 \mathrm{a}^{\dagger}$ & $7.16 \mathrm{a}$ & $8.40 \mathrm{a}$ \\
T2 & Trichoderma fasciculatum & $0.73 \mathrm{bc}$ & $1.11 \mathrm{~b}$ & $4.26 \mathrm{ab}$ \\
T3 & T. virens Strain G-41 & $0.70 \mathrm{c}$ & $1.40 \mathrm{~b}$ & $2.46 \mathrm{~b}$ \\
T4 & T. reesei & $0.71 \mathrm{c}$ & $0.85 \mathrm{~b}$ & $3.00 \mathrm{~b}$ \\
T5 & T. asperellum Strain CSAEGro-1 & $0.94 \mathrm{~b}$ & $1.68 \mathrm{~b}$ & $2.60 \mathrm{~b}$ \\
T6 & T. asperellum Strain CSAEGro-2 & $0.62 \mathrm{c}$ & $1.03 \mathrm{~b}$ & $4.26 \mathrm{ab}$ \\
T7 & Trichoderma sp. Strain Santa Teresa & $0.78 \mathrm{bc}$ & $1.05 \mathrm{~b}$ & $4.37 \mathrm{ab}$ \\
$P$-value & & $<0.0001$ & $<0.0001$ & 0.0042 \\
HSD & & 0.22 & 1.00 & 4.47 \\
\hline
\end{tabular}

${ }^{\dagger}$ Values of means with equal letters in the same column are not statistically different (Tukey, $\left.\alpha=0.05\right)$. HSD: Tukey's Honest Significant Difference.

derma virens strain G-41 (commercial strain) and T. asperellum strain CSAEGro-1 (native strain) with 2.46 and $2.60 \mathrm{~cm}$, respectively (Table 2); for these same isolates the highest inhibition percentage of the pathogen was obtained on the last evaluation date (70.72 and 69\%) (Fig. 4). The $S$. rolfsii grew at a rate of $2.8 \mathrm{~cm} \mathrm{day}^{-1}$. At the end of the experiment, $T$. fasciculatum, $T$. reesei, $T$. asperellum strain CSAEGro-2 and Trichoderma asperellum Santa Teresa, registered fungistatic activity on the pathogen. There are reports that the secondary metabolites of Trichoderma spp. produces enzymes (glucanases and chitinases), antibiotics (viridina, gliotoxin or peptaiboles) and mycotoxins (Shoresh and Harman, 2008), which are involved in the fungistatic effect Trichoderma produces against fungal pathogens such as $S$. rolfsii (Hirpara et al., 2017). The results obtained in the present experiment with $T$. virens are different to those reported by Parmar et al. (2015), who studied, antibiosis of various Trichoderma strains in vitro in the biocontrol of $S$. rolfsii isolated from peanut. In which, $50 \%$ inhibition was obtained with $T$. virens. In this regard, Hirpara et al. (2017) found that Trichoderma virens presented $76.37 \%$ inhibition of $S$. rolfsii growth in vitro at $144 \mathrm{~h}$; this average effectiveness is similar to $70.72 \%$ obtained in the present study, where the maximum inhibition was found using $T$. virens strain G-41 (PHC RootMate ${ }^{\circledR}$ Plant Health Care, Mexico City, Mexico), but in half the time (72 h). The difference in these results may be explained by the incubation conditions, which may affect the diffusion of secondary metabolites by the biocontrol agent and the pathogen development (Infante et al., 2011). Alvarado-Marchena and Rivera-Méndez (2016) evaluated in vitro the efficiency of Trichoderma asperellum against Sclerotium cepivorum isolated from onion, and found that the pathogen growth inhibition ranged from 47.3 to $61.08 \%$, the maximum inhibition reported by these authors is lower than $69 \%$ obtained with $T$. asperellum strain CSAEGro-1, but with the species $S$. rolfsii. John 


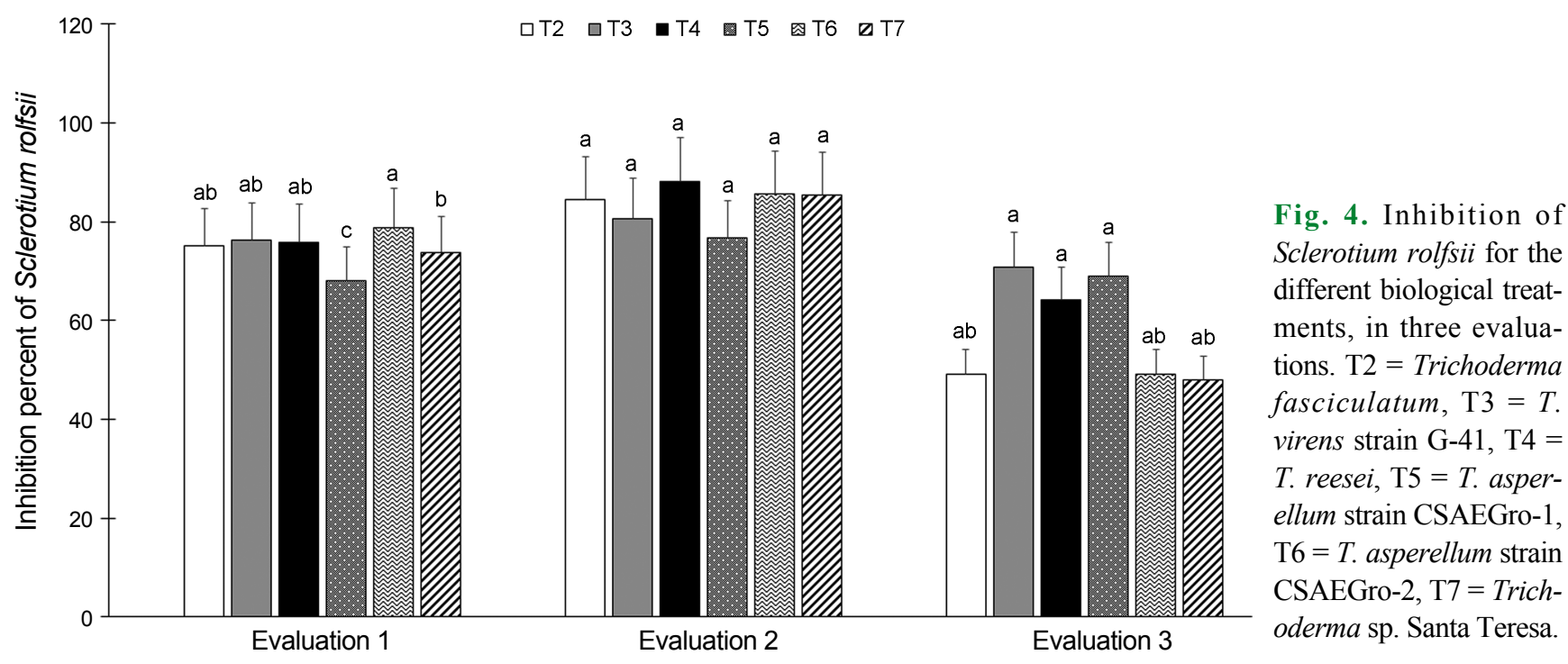

et al. (2015) evaluated in vitro the antibiosis of different Trichoderma asperellum strains against Sclerotium rolfsii and found that the pathogen growth inhibition ranged from 42.71 to $100.00 \%$, mean values that are within the range and above that obtained by the native $T$. asperellum strain CSAEGro-1. Native strains are an important option to be included in a management plan, as was confirmed in the present study, where the native $T$. asperellum strain CSAEGro-1, was found to be one of the most outstanding biocontrol agents against $S$. rolfsii in vitro. This agrees with that reported for native $T$. asperellum strain Csaegro-1, which has been evaluated against Rhizoctonia solani and Phytophthora capsici isolated from pipiana pumpkin, in which the appearance of these pathogens observed in vitro was delayed between 4 and 6 days in inoculated pipiana pumpkin fruits (Díaz et al., 2014, 2015).
Chemical control of Sclerotium rolfsii, the causal agent of rot in pumpkin fruit in vitro. In the four sampling dates, highly significant differences $(P<0.0001)$ were found because all the evaluated fungicides totally suppressed the colony growth of $S$. rolfsii, with the exception of thiophanate methyl, in which there was an average growth that fluctuated between $0.76 \mathrm{~cm}$ in the first evaluation and $8.05 \mathrm{~cm}$ at the end of the experiment (Table 3). For the experimental units of the control treatment, the pathogen had an average growth rate of $2.1 \mathrm{~cm} \mathrm{day}^{-1}$. At the end of this experiment, the majority of the fungicides inhibited $S$. rolfsii at $100 \%$, in comparison with the fungistatic activity presented by thiophanate methyl. Khan and Javaid (2015) evaluated the fungicide metalaxyl in vitro, to control the isolate $S$. rolfsii obtained from chickpea. They reported that this product inhibited the growth of pathogen by $100 \%$. This result is similar to that obtained with

Table 3. Average values of the diameter of the colony of Sclerotium rolfsii, in Test II of effect in vitro, using chemical fungicides

\begin{tabular}{|c|c|c|c|c|c|}
\hline \multirow{2}{*}{ Treatments } & \multirow{2}{*}{ Fungicides } & \multicolumn{4}{|c|}{ Diameter $(\mathrm{cm})$ of the colony of $S$. rolfsii } \\
\hline & & Sampling 1 & Sampling 2 & Sampling 3 & Sampling 4 \\
\hline $\mathrm{T} 1$ & Control & $1.25 \mathrm{a}^{\dagger}$ & $3.53 \mathrm{a}$ & $6.93 \mathrm{a}$ & $8.40 \mathrm{a}$ \\
\hline $\mathrm{T} 2$ & Metalaxyl & $0.00 \mathrm{c}$ & $0.00 \mathrm{c}$ & $0.00 \mathrm{c}$ & $0.00 \mathrm{c}$ \\
\hline $\mathrm{T} 3$ & Pyraclostrobin & $0.00 \mathrm{c}$ & $0.00 \mathrm{c}$ & $0.00 \mathrm{c}$ & $0.00 \mathrm{c}$ \\
\hline $\mathrm{T} 4$ & Thiophanate methyl & $0.76 \mathrm{~b}$ & $2.55 \mathrm{~b}$ & $5.70 \mathrm{~b}$ & $8.05 \mathrm{~b}$ \\
\hline $\mathrm{T} 5$ & Quintozene PCNB & $0.00 \mathrm{c}$ & $0.00 \mathrm{c}$ & $0.00 \mathrm{c}$ & $0.00 \mathrm{c}$ \\
\hline T6 & Cyprodinil + fludioxonil & $0.00 \mathrm{c}$ & $0.00 \mathrm{c}$ & $0.00 \mathrm{c}$ & $0.00 \mathrm{c}$ \\
\hline $\mathrm{T} 7$ & Procloraz & $0.00 \mathrm{c}$ & $0.00 \mathrm{c}$ & $0.00 \mathrm{c}$ & $0.00 \mathrm{c}$ \\
\hline$P$-value & & $<0.0001$ & $<0.0001$ & $<0.0001$ & $<0.0001$ \\
\hline HSD & & 0.20 & 0.79 & 1.00 & 0.22 \\
\hline
\end{tabular}

${ }^{\dagger}$ Values of means with equal letters in the same column are not statistically different (Tukey, $\left.\alpha=0.05\right)$. HSD: Tukey's Honest Significant Difference. 
the same fungicide against $S$. rolfsii isolated from pipiana pumpkin in the present experiment. Other studies have evaluated the sensitivity of $S$. rolfsii in vitro to some fungicides. For example, Mahato et al. (2014) evaluated several fungicides, where the active ingredient metalaxyl inhibited the growth of the pathogen by $94.04 \%$; this percentage is similar to the value obtained with metalaxyl in the present experiment. These results were possible because metalaxyl belongs to the phenylamides group, which inhibits the synthesis of ribonucleic acid (RNA), affecting mycelial growth, spore formation and pathogen infection (Fishel and Dewdney, 2012). Liang et al. (2015) evaluated the effect of pyraclostrobin on Sclerotinia sclerotiorum, and reported that close to $100 \%$ inhibition was obtained when using salycilhydroxamic acid. Without the latter, the inhibition was significantly reduced. On the other hand, Amule et al. (2014) reported that pyraclostrobin inhibited by $100 \%$ the development of $S$. rolfsii in vitro obtained from chickpea. This result is similar to the $100 \%$ obtained with this fungicide in the present study. According to Fishel and Dewdney (2012), pyraclostrobin affects mitochondrial respiration that discontinues energy production causing the death of phytopathogenic fungus. In the present study, thiophanate methyl produced fungistatic effect because it allowed 95.83 and $4.17 \%$ mycelial growth and inhibition, respectively. These results differ from those reported by Suryawanshi et al. (2015), who obtained the inhibition of $S$. rolfsii with thiophanate methyl by $63.81 \%$. However, the fungistatic effect of thiophanate methyl observed in the present study coincides with that reported by Manu et al. (2012), because with this same product they registered $0 \%$ inhibition on $S$. rolfsii in vitro; that is, the fungus grew $100 \%$ in the culture medium prepared with the fungicide. In the present study, quintozene inhibited the development of S. rolfsii by $100 \%$. In other similar studies, García et al. (2012) found that with quintozene, there were mycelial growth and inhibition by 17.38 and $82.62 \%$ in vitro, but against Rosellinia necatrix who is an inhabitant of the soil. Fishel and Dewdney (2012) mentioned that mode of action of quintozene is not fully known, but they propose that it interferes with the synthesis of lipids and cell membranes, which directly affects the mycelial growth of the fungi. The fungicide SWITCH ${ }^{\circledR}$ 62.5 (Syngenta Australia Pty Ltd., Macquarie Park, Australia) (cyprodinil + fludioxonil) was tested in vitro against the mycelial growth of Sclerotium cepivorum isolated from garlic (Allium sativum L.) by Pérez et al. (2015). They found that this product inhibited mycelial growth of the fungus by $1.0 \mathrm{~cm}$, representing $11.76 \%$ growth and $88.24 \%$ inhibition; inhibition percentage for $S$. rolfsii lower than $100 \%$ was recorded in the present study. On the other hand, Ayala et al. (2015) studied the effect of the fungicides SWITCH ${ }^{\circledR}$ 62.5 WG (cyprodinil + fludioxonil) and Sportak (prochloraz) in vitro on the growth of Sclerotinia sclerotiorum isolated from bean plants. They reported $100 \%$ inhibition of the two products; this value is similar to those obtained in these same treatments evaluated against Sclerotium rolfsii in this study. Mueller and Bradley (2008) commented that cyprodinil inhibits the synthesis of amino acid, and interferes the penetration and fungal growth both inside and outside the area where the product is applied. On the other hand, fludioxonil neutralizes the transduction pathway of the osmotic signal, which affects spore germi-

Table 4. Combined analysis of the treatments including Trichoderma spp. and fungicides on the production of healthy and damaged fruits and seed yield in the cultivation of pipiana squash (Cucurbita argyrosperma), through the 2015 and 2016 cycles

\begin{tabular}{clll}
\hline Treatments & \multicolumn{1}{c}{ NHF } & NDF & SY $(\mathrm{kg})$ \\
\hline T1 & $12.250 \mathrm{e}^{\dagger}$ & $11.0000 \mathrm{a}$ & $367.86 \mathrm{~d}$ \\
T2 & $29.750 \mathrm{a}$ & $2.3750 \mathrm{c}$ & $901.64 \mathrm{a}$ \\
T3 & $27.625 \mathrm{abc}$ & $3.8750 \mathrm{bc}$ & $833.82 \mathrm{ab}$ \\
T4 & $19.250 \mathrm{~d}$ & $9.1250 \mathrm{a}$ & $588.25 \mathrm{c}$ \\
T5 & $26.875 \mathrm{abc}$ & $3.1250 \mathrm{bc}$ & $825.75 \mathrm{ab}$ \\
T6 & $28.125 \mathrm{ab}$ & $2.5000 \mathrm{c}$ & $883.89 \mathrm{ab}$ \\
T7 & $26.875 \mathrm{abc}$ & $3.6250 \mathrm{bc}$ & $805.79 \mathrm{ab}$ \\
T8 & $26.250 \mathrm{abc}$ & $3.7500 \mathrm{bc}$ & $802.54 \mathrm{ab}$ \\
T9 & $27.500 \mathrm{abc}$ & $3.5000 \mathrm{bc}$ & $831.86 \mathrm{ab}$ \\
T10 & $24.125 \mathrm{bc}$ & $5.8750 \mathrm{~b}$ & $729.46 \mathrm{bc}$ \\
T11 & $25.500 \mathrm{bc}$ & $2.8750 \mathrm{c}$ & $815.93 \mathrm{ab}$ \\
T12 & $26.625 \mathrm{abc}$ & $3.6250 \mathrm{bc}$ & $841.54 \mathrm{ab}$ \\
T13 & $23.875 \mathrm{c}$ & $5.2500 \mathrm{bc}$ & $745.32 \mathrm{abc}$ \\
HSD & 4.0067 & 2.9986 & 169.3 \\
Cycle & & & \\
Spring-Summer 2015 & $27.6154 \mathrm{a}$ & $1.6346 \mathrm{~b}$ & $852.02 \mathrm{a}$ \\
Spring-Summer 2016 & $22.3269 \mathrm{~b}$ & $7.6731 \mathrm{a}$ & $682.39 \mathrm{~b}$ \\
HSD & 0.8182 & 0.5686 & 24.477 \\
\hline
\end{tabular}

Values of means with equal letters in the same column are not statistically different (Tukey, $\alpha=0.05$ ). NHF $=$ Number of healthy fruits harvested in $35 \mathrm{~m}^{2}, \mathrm{NDF}=$ Number of damaged fruits harvested in $35 \mathrm{~m}^{2}$, SY $=$ Seed yield in $\mathrm{kg} \mathrm{ha}^{-1} . \mathrm{T} 1=$ Control, $\mathrm{T} 2=T$. asperellum $($ CSAEGro-1) + metalaxyl, T3 $=$ T. asperellum $($ CSAEGro-1) + pyraclostrobin, $\mathrm{T} 4=T$. asperellum (CSAEGro-1) + methyl thiophanate, $\mathrm{T} 5=T$. asperellum (CSAEGro-1) + quintozene, T6 $=$ T. asperellum (CSAEGro-1) + cyprodinil + fludioxonil, $\mathrm{T} 7=$ T. asperellum (CSAEGro-1) + prochloraz, T8 = Trichoderma virens (PHC RootMate $\left.^{\circledR}\right)+$ metalaxyl, T9 $=$ Trichoderma virens $\left(\right.$ PHC RootMate $\left.{ }^{\circledR}\right)$ + pyraclostrobin, T10 $=$ Trichoderma virens $\left(\right.$ PHC RootMate ${ }^{(\mathbb{R})}+$ methyl thiophanate, T11 $=$ Trichoderma virens $\left(\mathrm{PHC}\right.$ RootMate $\left.{ }^{\mathbb{R}}\right)+$ quintozene, T12 = Trichoderma virens $\left(\right.$ PHC RootMate $\left.{ }^{\circledR}\right)+$ cyprodinil + fludioxonil, T13 = Trichoderma virens $\left(\right.$ PHC RootMate $\left.{ }^{\mathbb{B}}\right)+$ prochloraz, HSD: Tukey's Honest Significant Difference. 
Table 5. Analysis of the factorial structure not including the control treatment of the crop cycle 2015 and 2016, strains of Trichoderma spp. and fungicides, on the obtaining of healthy fruits, damaged and seed yield, in the cultivation of Pipiana squash $(\mathrm{Cu}$ curbita argyrosperma)

\begin{tabular}{lccc}
\hline \multicolumn{1}{c}{ Factors } & NHF & NDF & SY \\
\hline Cycle & & & \\
Spring-Summer 2015 & $28.6667 \mathrm{a}^{\dagger}$ & $1.1458 \mathrm{~b}$ & $885.60 \mathrm{a}$ \\
Spring-Summer 2016 & $23.3958 \mathrm{~b}$ & $7.1042 \mathrm{a}$ & $715.36 \mathrm{~b}$ \\
HSD & 0.7957 & 0.7974 & 24.619 \\
Trichoderma & & & \\
T. asperellum (CSAEGro-1) & $26.4167 \mathrm{a}$ & $4.1042 \mathrm{a}$ & $806.52 \mathrm{a}$ \\
T. virens (PHC RootMate ${ }^{\mathbb{R}}$ ) & $25.6458 \mathrm{a}$ & $4.1458 \mathrm{a}$ & $794.44 \mathrm{a}$ \\
HSD & 1.4487 & 0.6902 & 51.395 \\
Fungicides & & & \\
Metalaxyl & $28.0000 \mathrm{a}$ & $3.0625 \mathrm{~b}$ & $852.09 \mathrm{a}$ \\
Pyraclostrobin & $27.5625 \mathrm{ab}$ & $3.6875 \mathrm{~b}$ & $832.84 \mathrm{a}$ \\
Thiophanate methyl & $21.6875 \mathrm{c}$ & $7.5000 \mathrm{a}$ & $658.86 \mathrm{~b}$ \\
Quintozene (PCNB) & $26.1875 \mathrm{ab}$ & $3.0000 \mathrm{~b}$ & $820.84 \mathrm{a}$ \\
Cyprodinil + fludioxonil & $27.3750 \mathrm{ab}$ & $3.0625 \mathrm{~b}$ & $862.71 \mathrm{a}$ \\
Procloraz & $25.3750 \mathrm{~b}$ & $4.4375 \mathrm{~b}$ & $775.55 \mathrm{a}$ \\
HSD & 2.428 & 1.7429 & 104.78 \\
\hline
\end{tabular}

${ }^{\dagger}$ Values of means with equal letters in the same column are not statistically different (Tukey, $\alpha=0.05$ ). NHF $=$ Number of healthy fruits harvested in $35 \mathrm{~m}^{2}, \mathrm{NDF}=$ Number of damaged fruits harvested in $35 \mathrm{~m}^{2}, \mathrm{SY}=$ Seed yield ha ${ }^{-1}$ in $\mathrm{kg}$. HSD: Tukey's Honest Significant Difference.

nation and mycelial growth. The azole group of fungicides including the active ingredient prochloraz, which has an inhibitory effect on the biosynthesis of ergosterol, necessary for the formation of cell membranes, permits the adequate pathogen control.

Integrated control of Sclerotium rolfsii, causal agent of rot in pumpkin fruits in field conditions. Number of commercial fruits. Significant differences were found among treatments $(P<0.0001)$; the averages fluctuated from 12.25 to 29.75 . The control obtained the lowest incidence of mature fruits without damage by the pathogen. The highest average was obtained by the native Trichoderma asperellum strain CSAEGro-1 + metalaxyl (T2) (Table 4). On the other hand, during the spring-summer 2015 cycle, more commercial fruits were harvested (Table 4), because in this year there was little rainfall, which lowered the incidence caused by the pathogen. In the combined analysis used to determine the effect of the strain and fungicide of the crop cycles, the best yield was recorded in the spring-summer 2015 season and was obtained by the native $T$. asperellum strain CSAEGro-1 and the fungicide Metalaxyl (Table 5).
Rather et al. (2012) evaluated the effect of metalaxyl and Trichoderma virens strains, against Fusarium oxysporum, Phytophthora capsici, Rhizoctonia solani and Sclerotium rolfsii, pathogens that cause wilt in pepper, under field conditions. They reported that with these two treatments when applied individually register averages of disease incidence of 30 and $51.9 \%$, respectively; but when using metalaxyl + Trichoderma virens the disease incidence was significantly reduced to $27.3 \%$. These results coincide with those obtained in this study with Trichoderma asperellum (CSAEGro-1) + metalaxyl, which produced the lowest disease incidence by Sclerotium rolfsii in pipana pumpkin fruits in the field and, consequently, a higher number of commercial fruits were obtained. These findings demonstrate that by combing the different control methods reduces the pathogens damage, which directly affects the harvest of more commercial fruits per cultivated unit area. Number of noncommercial fruits. This characteristic showed significant differences due to the effect of treatments, crop cycles and fungicides $(P<0.0001)$, but the strains showed a similar behavior. The highest fruit rot incidence was presented by the control, which fluctuated from 2.37 to 11 . The lowest fruit damage was obtained by $T$. asperellum (CSAEGro-1) + metalaxyl (T2) (Table 4). On the other hand, in the spring-summer 2015 cycle, less fruit damage was obtained during harvesting (Table 5). From combined analysis, the fungicide quintozene used in the spring-summer 2015 cycle obtained the lowest damage observed in fruits; On the other hand, the treatments T. asperellum (CSAEGro-1) and $T$. virens strains (PHC RootMate ${ }^{\circledR}$ ) produced similar behavior regarding the fruit rot incidence (Table 5). Islam et al. (2016) evaluated Trichoderma species in controlling tomato stem rot caused by Sclerotium rolfsii; They found that with $T$. asperellum the disease incidence was reduced; the effect was more consistent when the biocontrol agent was inoculated in the seed and applied to the soil; in the present study similar results was obtained because $T$. asperellum (CSAEGro-1) decreased the incidence of rot in pipana pumpkin fruits; although the lowest fruit damage was recorded when combing $T$. asperellum + metalaxyl. In this regard, Mueller and Bradley (2008) argued that the phenylamide group presents systemic properties, so when they penetrate the plant, they are transported systemically to the fruits and protects them against an infection by $S$. rolfsii. In the analysis of the fungicide effect, quintozene suppressed the incidence of the pathogen and registered lower fruit damage; the positive effect of quintozene was because it affects the integrity of the cell membrane and cell wall, as well as the mitochondria in the phytopathogenic fungi, which decreases the formation of infectious 
sclerotia and propagules (Latin, 2011). Likewise, the climate played an important role in reducing damages in the 2015 cycle, since the average registered rainfall was only $145 \mathrm{~mm}$, during the growing cycle (June-October). Seed yield in $\mathrm{kg} \mathrm{ha}^{-1}$. This component is of great interest because it determines the productivity and profitability that this crop can generate. Significant difference was obtained only by the effect of treatments, cultivation cycle, and fungicides $(P<0.0001)$. The multiple mean comparison test showed that the highest yields were 901.64 and $883.89 \mathrm{~kg}$ $\mathrm{ha}^{-1}$, which were obtained by the treatments $T$. asperellum (CSAEGro-1) + metalaxyl and T. asperellum (CSAEGro-1) + cyprodinil + fludioxonil, respectively. The highest yield was obtained in the spring-summer 2015 cycle, because less rainfall occurred in this cycle, compared to the springsummer 2014 cycle (Table 4). The individual effect of the fungicides allowed us to know that the mixture of cyprodinil + fludioxonil was the most outstanding treatment, obtaining the highest seed yield, $862.71 \mathrm{~kg} \mathrm{ha}^{-1}$. Although no significant differences were found between the two evaluated strains, $T$. asperellum (CSAEGro-1) recorded a slightly higher seed yield than the commercial $T$. virens strain (PHC RootMate ${ }^{\circledR}$ ) (Table 5). These results are consistent with Rather et al. (2012), who mention that the use of metalaxyl + Trichoderma sp. reduces the incidence of wilt in pepper (Capsicum annum L.) and promotes higher yields. Akgul et al. (2011) applied several fungicides in the field to control $S$. rolfsii in peanut, and found that metalaxyl decreased the incidence of the pathogen and also increased yields; the data reported by these authors coincides with the field results obtained in the present study, because the highest yields were produced by metalaxyl and Trichoderma; Finally, Mouden et al. (2016) recently studied the effect of cyprodinil + fludioxonil in vivo to control Botrytis cinerea and Colletotrichum gloeosporioides in strawberry; they reported that cyprodinil + fludioxonil was the most effective because it presented $100 \%$ inhibition; the effective control of pathogens by using these chemical fungicides corroborates that these products have great potential and should be incorporated into the integrated management of pests and disease, as obtained in the present investigation. These active ingredients protect pumpkin fruits from infection and help to obtain the highest seed yield in the field. The results obtained by Trichoderma are due to its rapid growth, wide ecological plasticity, mechanisms of direct action (competition, antibiosis and mycoparasitism), which manifest their antagonistic potential against plant pathogens such as S. Rolfsii (Infante et al., 2011); this encourages the incorporation of species such as Trichoderma asperellum in the integrated management of this pest and diseases under field conditions, which permits acceptable commercial yields of pumpkin seed as was identified in the present study.

\section{References}

Akgul, D. S., Ozgonen, H. and Erkilic, A. 2011. The effects of seed treatments with fungicides on stem rot caused by Sclerotium rolfsii Sacc., in peanut. Pak. J. Bot. 43:2991-2996.

Alvarado-Marchena, L. and Rivera-Méndez, W. 2016. Molecular identification of Trichoderma spp. in garlic and onion fields and in vitro antagonism trials on Sclerotium cepivorum. Rev. Bras. Cienc. Solo. 40:e0150454.

Amule, R., Gupta, O. and Mishra, M. 2014. Techniques for screening of chickpea genotypes against collar rot, its management through host plant resistance and fungicides. Legume Res. 37:110-114.

Ayala, A. Q. A., Cortez, M. E., Apodaca, S. M. Á., Leal, L. V. M., Valenzuela, E. F. A. and Palacios, M. C. A. 2015. Bio-rational and conventional fungicides effectiveness on in vitro Sclerotinia sclerotiorum. Mexican Journal of Agricultural Sciences 11:2149-2156.

Ayvar, S. S., Mena, B. A., Durán, R. J. A., Cruzaley, S. R. and Gómez, M. N. O. 2007. The pipiana pumpkin and its integrated management. Technical brochure. Fundación Produce de Guerrero, A. C. Campo Experimental Iguala. CSAEGro. Iguala, Gro. México. 26 pp.

Díaz, N. J. F., Alvarado, G. O. G., Leyva, M. S. G., Ayvar, S. S., Michel, A. A. C. and Vargas, H. M. 2015. Identification and control of fungi causing fruits rot in pipiana pumpkin (Cucurbita argyrosperma Huber). Afr. J. Agric. Res. 10:1150-1157.

Díaz, N. J. F., Vargas, H. M., Ayvar, S. S., Alvarado, G. O. G., Solís, A. J. F., Durán, R. J. A., Díaz, C. H. L. and Hernández, A. A. 2014. Morphological and PCR identification of Rhizoctonia solani $\mathrm{KÜHN}$ isolated from pipiana pumpkin fruits and greenhouse management. Biotecnia 16:17-21.

Felsenstein, J. 1985. Confidence limits of phylogenies: an approach using the bootstrap. Evolution 39:783-791.

Fishel, F. M. and Dewdney, M. M. 2012. Fungicide Resistance Action Committeés (FRAC) Classification scheme of fungicidees according to mode of action. PI94. University of Florida. 7 pp.

García, V. R., González, D. J. G., Domínguez, A. G., Ayala, E. V. and Aguilar, M. S. 2012. Rosellinia necatrix in Rosa sp. and an evaluation of its sensitivity to fungicides. Rev. Chapingo Ser. Hortic 18:39-54.

Hall, T. 2004. BioEdit version 7.0.0. Isis Pharmaceuticals Inc. 192 pp. URL http://www.mbio.ncsu.edu/ BioEdit/biodoc.pdf/.

Hirpara, D. G., Gajera, H. P., Hirpara, H. Z. and Golakiya, B. A. 2017. Antipathy of Trichoderma against Sclerotium rolfsii Sacc.: evaluation of cell wall-degrading enzymatic activities and molecular diversity analysis of antagonists. J. Mol. Microbiol. Biotechnol. 27:22-28.

Infante, D., González, N., Reyes, Y. and Martínez, B. 2011. Evaluation of the effectiveness of twelve strains of Trichoderma 
asperellum Samuels on three phytopathogens in field conditions. Journal Plant Protection 26:194-197.

Islam, M. M., Delwar, M., Hossain, M. N. and Naoki, H. 2016. Biological control of tomato collar rot induced by Sclerotium rolfsii using Trichoderma species isolated in Bangladesh. Arch. Phytopathology Plant Protect. 50:109-116.

John, N. S., Anjanadevi, I. P., Nath, V. S., Sankar, S. A., Jeeva, M. L., John, K. S. and Misra, R. S. 2015. Characterization of Trichoderma isolates against Sclerotium rolfsii, the collar rot pathogen of Amorphophallus - a polyphasic approach. Biol. Control 90:164-172.

Khan, I. H. and Javaid, A. 2015. Chemical control of collar rot disease of chickpea. Pak. J. Phytopathol. 27:61-68.

Kumar, S., Stecher, G. and Tamura, K. 2016. MEGA7: molecular evolutionary genetics analysis version 7.0 for bigger datasets. Mol. Biol. Evol. 33:1870-1874.

Latin, R. 2011. Practical guide to turfgrass fungicides. APS Press, MN, USA. 270 pp.

Liang, H. J., Di, Y. L., Li, J. L., You, H. and Zhu, F. X. 2015. Baseline sensitivity of pyraclostrobin and toxicity of SHAM to Sclerotinia sclerotiorum. Plant Dis. 99:267-273.

Mahato, A., Mondal, B., Dhakre, D. S. and Khatua, D. C. 2014. In vitro sensitivity of Sclerotium rolfsii towards some fungicides and botanicals. Scholars Acad. J. Biosci. 2:467-471.

Manu, T. G., Nagaraja, A., Janawad, C. S. and Hosamani, V. 2012. Efficacy of fungicides and biocontrol agents against Sclerotium rolfsii causing foot rot disease of finger millet, under in vitro conditions. GJBAHS 1:46-50.

Mouden, N., Chliyeh, M., Benkirane, R., Ouazzani, A. T. and Douira, A. 2016. Chemical control of some strawberries fungal pathogens by foliar fungicides under in vitro and in vivo conditions. Int. J. Recent Sci. Res. 7:9037-9051.

Mueller, D. S. and Bradley, C. A. 2008. Field crop fungicides for the North Central United States. North Central Integrated Pest Management Center. 29 pp.

Parmar, H. J., Bodar, N. P., Lakhani, H. N., Patel, S. V., Umrania, V. V. and Hassan, M. M. 2015. Production of lytic enzymes by Trichoderma strains during in vitro antagonism with Sclerotium rolfsii, the causal agent of stem rot of groundnut. Afr. J. Microbiol. Res. 9:365-372.

Patil, N. N., Waghmo de M. S., Gaikwad, P. S., Gajbhiye, M. H., Gunjal, A. B., Nawani, N. and Kapadnis, B. P. 2014. Potential of Microbispora sp. V2 as biocontrol agent against Sclerotium rolfsii, the causative agent of southern blight of Zea mays L. (Baby corn)--in vitro studies. Indian J. Exp. Biol. 52:11471151.

Pérez, M. L., Belmonte, V. J. R., Núñez, Palenius, H. G., Guzmán, M. R. and Mendoza, C. B. 2015. In vitro sensitivity of two species of Sclerotinia spp. and Sclerotium cepivorum to agents of biological control and fungicides. Mexican Journal of Phytopathology 33:256-267.

Rather, T. R., Razdan, V. K., Tewari, A. K., Shanaz, E., Bhat, Z. A., Hassan, M. G. and Wani, T. A. 2012. Integrated management of wilt complex disease in bell pepper (Capsicum annuum L.) J. Agric. Sci. 4:141-147.

Shoresh, M. and Harman, G. E. 2008. The molecular basis of shoot responses of maize seedlings to Trichoderma harzianum T22 inoculation of the root: a proteomic approach. Plant Physiol. 147:2147-2163.

Sohbat, B., Reza, A. and Saeed, A. 2015. Anti-fungal properties of 43 plant species against Alternaria solani and Botrytis cinerea. Arch. Phytopathology Plant Protect. 48:336-344.

Statistical Analysis System. 2015. SAS user's guide: statistics. Release 6.03. SAS Institute in corporation, Cary, NC, USA.

Suryawanshi, A. P., Borgaonkar, A. S., Kuldhar, D. P. and Dey, U. 2015. Integrated management of collar rot (Sclerotium rolfsii) of brinjal (Solanum melongena). Indian Phytopath. 68:189195.

Thompson, J. D., Higgins, D. G. and Gibson, T. J. 1994. CLUSTAL W: improving the sensitivity of progressive multiple sequence alignment through sequence weighting, positionspecific gap penalties and weight matrix choice. Nucleic Acids Res. 22:4673-4680.

Watanabe, T. 2002. Pictorial atlas of soil and seed fungi. Morphologies of cultured fungi and key to species. 2nd ed. CRC Press, Washington DC, USA. 500 pp.

White, T. J., Bruns, T., Lee, S. and Taylor, J. 1990. Amplification and direct sequencing of fungal ribosomal RNA genes for phylogenies. In: PCR protocols, eds. by M. A. Inns, D. H. Gelfland, J. J. Sninsky and T. J. White, pp. 315-322. Academic Press, CA, USA.

Zitter, T. A., Hopkins, D. L. and Thomas, C. E. 2004. Pests and diseases of cucurbits. The American Phytopathological Society, Ediciones Mundi Prensa. 88 pp. 